\title{
ISSUE OF FEDERAL SYSTEM IN NEPAL
}

\author{
Tara Nath Ghimire ${ }^{1}$
}

\begin{abstract}
Federal process of Nepal has been guided by some major factors such as elimination of discrimination, equal regional development and political participation. Federalism has been a crucial issue of modern Nepal. The issue of federalism has not been guided by remote past as a vital demand because Nepal has adopted a long history of unitary system. But some regional and marginalized groups have been demanding it since 1950, who were struggling against discriminations. Federalism was not documented even in an initiate part of Interim Constitution 2006. It was also not agenda of Maoist Party which they had put in forty points demand letter. It wasn't materialized till peoples' movement second. It is supposed that federalism can bring miraculous modification as to solve problems of inequity and marginalization than in the unitary system. Some political parties have documented in their manifesto that federal system is only the alternation for prosperity in Nepal. But it might be incorrect supposition. Long route of unitary system of Nepal was led by few elites, who were specially professed Hindus. Monarchy was also surrounded by prevailing castes. Due to these various reasons conflict began in Nepal which has developed as transitional movement of chronic infection. The issue of federal system is emerged by those who are struggling against discriminations and they want to abolish all kind of social discriminations, problems of regional, religion, gender, cast, and poverty. Aspirations of ownership of all segments and development of nation have guided to make federal state in Nepal.
\end{abstract}

Keywords: Federalism, Restructure, Development, Discriminations, Inclusive, Unitary.

1 Dr. Ghimire is a Lecturer, Political Science Department, Ratna Rajya Laxmi Campus, Kathmandu, TU. 


\section{ISSUE OF FEDERAL SYSTEM IN NEPAL}

\section{INTRODUCTION}

Nepal is in the process of institutionalizing federal system. The issue of federalism does not have a long history in Nepal but some ethnic groups demanded it for a long time. The federal system has come to the forefront of the state restructuring process in Nepal. Gender, caste; regional and religious discrimination and poverty were major challenges for the unitary system. Federal concept of Nepal has come to solve all these problems at once. Some principal causes have guided to transform the unitary system into federal system. In a unitary and federal system, the attainment of power and the division of power remain at the center. 'The early federalist statesmen and theories were preoccupied with theoretical concept like horizontal separation of power between the three classical organs of government on the one hand, and vertical of division powers between of federal and regional government on the other'(Saxena 2011). It shows the structure of federal countries and division of power. Generally a federal government has the horizontal separation of power and vertically division of power. Montesquieu, in his book Spirit of Law describes, 'federalism as a collection of internal freedoms within a society, which is the government of internal security in the guise of liberty, the control of mutual balance', (Hueglion 2011).

Nepal was Hindu kingdom since 1824 B.S under the Shah Family. When it was divided in different parts with many small sates, King Pritivi Narayan Shah had integrated Nepal. He had been successful to make it a sovereign nation. That was an obligatory work to save national sovereignty. On the other hand, it has obtained a legitimate symbol as resolute wall from unsafe nationality. Since the unification, governing system was an absolute monarchy for two and half centuries.

Since the restoration of democracy in 1990, Nepal has practiced multiparty democratic system in place of absolute monarchy, which was the beginning of participatory power. The Constitution of Nepal 1990 had adapted decentralized system on three tiers. It had searched rights and power processing. That was a moment of participatory democracy in Nepal. It has generated various dimensions of awareness among backward communities. At that time some ethnics and regional groups had appeared for federalism for their rights and ownership 'although, Terai Congress had demanded a 'Terai autonomous state' after 1950, National Janamukti party, Nepal Rastiya janjati party as well as other different ethnic organizations 
had demanded for the federal structure state just after the movement of 1990' (Khanal 2009). Demand of federal system in Nepal has not been long proceeding, of course, since the Maoist movement began on 1996; it had formulated a strong wave in its underground political sphere. In fact, due to the strong demand of Terai Andolan 2006, the interim constitution of 2006 had to get the first amendment so as to adopt federalism to replace the long experience of unitary system. This study is sought why federal issue is raised in Nepal and how debate is going on as unsolved consequence.

\section{OBJECTIVES}

The principal objective of the study is to find developing issue of federalism in Nepalese politics. The article has tried to open about federal concept of Nepal that how and why the issue of federalism developed in Nepal and to seek probable outcome of federalism in Nepalese politics. This study is analyzed the causes and impact of it and also tried to find historical background to present situation for demand of federalism.

\section{LITERATURE REVIEW}

'Development of all federal states has been in accordance with time. Some of them have changed constitution formally but others have made remarkable changes even far better constitution. Formation of federal units, urbanization, vital changes in geographical and demographic changes, experience of democracy, new technology, and development arises in internal and worldwide politics are some major facts to keep federal experience in size. Searching of federal formula that eliminates conflicts and separation has been unsuccessful in other incidents (Srilanka \& Syprus). After the end of maoist revolution, recently, Nepal is studying about possibility of federalism' (Anderson 2007). Federalism of Nepal, especially after armed conflict, is applied for the conflict management, although inclusiveness and participation in politics and development are raised along with.

Federalism is not an ultimate goal of any state itself. Nicolo Topperwien describes, 'Federalism is certainly no miracle cure and may not be appropriate for all countries in all situations. There are successful examples of federal state, but also a long list of failed federation', (Topperwins 2009). The concept of federalism is a new discourse of Nepal. The aspirations of ownership and prosperity are the foremost reasons of it. Federal government, however, is not only alternative way of good governance for development and ownership. There are several examples of other successful nations where there is prosperity only having democracy. 


\section{ISSUE OF FEDERAL SYSTEM IN NEPAL}

On the other hand, unitary system of Nepal could not address such problems which are being raised by demanding federalism. In the rebellion time, Maoist had organized different Ethnic Liberation Front so that they could strategically be successful to lead the movement in 'People's War'. Krishna Khanal articulate, 'accordingly, different ethnic liberation fronts were formed with the slogans of 'Right to Self-determination' and 'ethnic autonomy' (Khanal 2009). At that time they had formed nine autonomous ethnic regions against Democratic centralism. Now, the structures, which they had formed during the war period has become a strong base for federalism that they still claim as the pioneer of federal structure in Nepal.

While Hindu king Prithivi Narayan Shah had unified the nation, there had been appeared a kind of 'victories pleasure' which did not acknowledge the rights of the communities. In this context Sanjib Upreti writes, 'As a consequence the Aryan people of the hill- who had emerged as victors in the war of Nepal's unification- not only became dominant politically, but also imposed their own language and culture upon the Janajatis and Hindus of the Terai. Even among the Aryan Hindus, the laws were not the same of the all' (Upreti 2009). Nepal had been governed by feudal system till democratic era. The first law of Nepal 'Civil Code 1854' B.S also categorized social offences punishable by law that was only on the favor of those privileges.

After the restoration of democracy in 1990, people were in practice of democracy. But shifting situation was not favorable to flourish it. Certain conditions of discrimination are still remained. Krishna Bhattatachan observes, 'changes have come and gone, peoples movements have come and gone, armed rebellions have come and gone, monarchy has come and gone, but Bahunbad or domination or hegemony of one caste (Bahun-Chhetries), one class (ruling), one region (the Hill) has stayed forever' (Bhattatachan 2008). The Constitutional practice by the elected leadership could not fulfill interests of people. On the other hand, Political parties had been unsuccessful to play good governance on their roadmap. Parliamentary exercise was declined on its ethical values. People's aspirations turned into depression though the system of democracy itself is universally acknowledged political system. Due to these factors Maoist insurgency became a crucial political force which had emerged to highlight the issue of federalism by healing slogans for all sorts of discriminations. 
Federalism is a shape of state to regulate law at local sites. In Nepal, Major political parties have not been able to give clear file of federal structure. On the other hand, some parties have been completely against the idea of federal state. 'Federalism is an idea whose importance is akin to natural law in defining justice and to natural right in delineating the origin and proper constitution society. Although, those foundations have been some what eclipsed since the shift to organic and then positivistic theories of politics, which begin in the mid nineteenth century, federalism as form of political organization has grown as a factor shaping political behavior' (Elazar 1991). However, the concept of federal structures in Nepal is neither guided by modern political trends nor by the traditional ones.

The Interim Constitution of Nepal has declared that inclusive federal government can bring positive consequence for all kinds of problems. This has been incorporated in the Interim Constitution by first amendment. Lok Raj Baral writes, 'The issue of federalism comes in the wake of reconstruction of the state, though many aspects regarding are not made clear by the political parties. However, the schedule of federalism has now become an agenda of national commitment with all parties and forces in Nepal committing them to transform Nepal into a federal state' (Baral 2009). Hence, Nepal is likely to introduce federal structure by deaggregation process.

Federalism is process of state formation. 'Federal idea is now more popular internationally that any time in history, this suggest that state builders should be wary of rejecting the advantages that so many elsewhere see in federal solutions' (Watts 2008). In order to establish federalism it requires many preparative stages for its maturity. Early history of federalism shows that two kinds of procedure are to be followed: federalism by deaggregation and federalism by aggregation. 'De-aggregation' process is a kind of procedure that leads centrifugal trend and 'aggregation' is another kind of procedure which deserves centripetal trend. In the modern era of state nations, American federalism has become the first modern model federal state which has emerged with a new system of politics. The American federalism has been made by centripetal process.

The base of formation of federalism in Nepal is religion and caste system. 'It was surprising to observe that such cast based politics could not make a major break with the past in the post Rana period also. The end of Ranarchy in 1950 and the drawn of multiparty democracy could not 


\section{ISSUE OF FEDERAL SYSTEM IN NEPAL}

bring about a qualitative change in the power structure' (Baral 2009). Some regional and marginalized groups has been demanded it since 1950, though they were struggling against discriminations. During Panchayat system it was on shadow. Since the restoration of democracy 1990, some ethnic groups have raised voice for the federal structure in Nepal.

\section{METHODOLOGY}

The study is based on secondary data only by using theoretical review. The study is analyzed about the developing issue of federalism of Nepal. Descriptive and analytical approach is used to analyze the data. It is used by different information based on the related subject. Identification of dependent variables and other methodological parts are consulted proper.

\section{Developing concept of federalism}

The foundation stone of federalism in Nepal is connected to state restructuring. The justification for federalism was linked to the restructuring of the state of Nepal in the desire for development and inclusive democracy. 'In the modern state, the attainment of power is the core of the central interest of its use and control. It is the principle of power division' (Ray 1999). Federal system is also a type of democratic government. There has been shared power between federal and regional units. Federal units are dividing by peoples' common interest and their valuable integrity. Due to sovereignty, unity, and development, the justification of federalism is becoming more relevant. The United State America is the first federal state in modern politics. 'Following it's confederation of revolution 1781, America had become a new independent federal state in 1787. Most of those who use it agree in this, they have in mind an association of states' (Wheare 1963). Following the recognition of America, many countries of the world have gone to federalism. Nepal has also chosen federalism in the restructuring of the state. In the political history of Nepal, federalism is not practiced. Nepal has been in federalism since the time of state restructuring.

'Prior to the unification of Nepal, independent small 'Baisi and Chaubisi' states ruled Nepal. During the unification, King Prithbi Narayan Shah united those small states on the strength of power (Regmi 2007). Due to this fact, no history of federalism and confederacy has been used in Nepal prior to unification. Since the unification era, there were uncounted problems. Regional discrimination, poverty and illiteracy were highlighted problems of unitary system. Issue of federalism, however, has not become the singular resolution among the mass in our context. Some causes are 
guided to develop federal concept. The unitary system was led by few elites, who were specially Hindus. Monarchy was also guided by those castes for a long time. The monarchy was bottom row of federalism itself which had always neglected the problem of regions, castes, ethnics, genders, religion and other social ills. Of course, those problems of Nepal were pressing issues. Nepal is a multicultural country and it has also difficult geographical location. Hillside of Nepal, which is a difficult structure. On the other hand, Language has been a crucial problem. 'These languages of about forty percent minorities are seeking to revive its strength against the national language Nepali' (CBS 2012). Languages, regional development, religions were made issues of federalism.

During the Rana Period, consequences for those marginalized communities remained much bitterer. 'The demand for autonomy in the Tarai had arisen in the democratic period, with the end of the Rana regime in Nepal. Later he joined himself in the reign of the king in 1949. Although the Terai Congress demanded a separate autonomous state in the Tarai in 1950, it could not be put into practice. Later he joined himself in the reign of the king in 1960' (Khanal 2009). Although the Terai Congress demanded autonomy, there was no demand for federalism. In that period of early democracy, there was no history of the demand for federalism from anywhere.

In Panchayat System, new Muliki Ain 2020 B.S had adapted as a codifying civil-law. Bright provisions of law could not implemented it's so as to enhance the social welfare of those communities. Constitution of the kingdom of Nepal 1990 was a strong Constitution for the Democratic value. During the democratic era since 1950 the dilemma of communities, hills and Terai Problems could not be resolved. It had ensured by new constitutions of 1990. There were acknowledged democratic norms, multi-party system, rule of law, delegation of power and common justice. But the 'Democratic' Government of Nepal had not recognized unmarked plan for the remote area, hillside, Terai and marginalized communities. People could not feel new prosperity in rooted problems those were deriving from a long course. They couldn't experience enhancement in their livelihood whereas only the limited elites again got privileges.

In Nepal, the issue of federal system has become a substantial agenda. After the third amendment of Interim Constitution 2006, Nepal has formally become a 'Federal Democratic Republic' nation even though 


\section{ISSUE OF FEDERAL SYSTEM IN NEPAL}

the first amendment of Interim Constitution had declared the restructure as inclusive, democratic and federal structure. Even the demand of federalism in Nepal was not an agenda of Maoist People's War that had happened to become a slogan of People's Movement Second. Since, the initial Interim Constitution 2006, it did not feel necessity to approve the federal restructure in its first draft. When the Interim Constitution of Nepal 2006 states that the restructuring of the state will be done in federalism through the amendment of Article 138 (10), federalism has been formally recognized in Nepal since that time.

After the 1990 change, the party led by Kaziman Kandamba demanded federalism, including twelve province states. But at the intervention of the government, the election Commission had banned that party, (Baral 2006). The Sadbhawana Party had also demanded federalism for its Birgunj Session 1993, with three states. In the election of 2006, the Sadbhawana Party in its election manifesto had forwarded a proposal for federalism with 5 states, while Kirat Workers Party also demanded a federal state with nine provinces (Nemakipa 2010).

Nepal Communist Party Maoist had declared the 'People's War' by endorsing its agenda of forty points to the government of Nepal in 1995. The revolt of Maoist was called for development in all segments and areas. Slowly, it had expanded over the country within a decade, turning it to be indispensable milestone of change. Maoist's had principle notion that the monarchy, feudal system and Indian expansionists were the main obstacles of development and prosperity in Nepal. The Maoist revolution was guided by the motto that Nepal would move forward after only abolition of the monarchy. After the dissolution of monarchy in Nepal, the demand of federal system had emerged. When Gyanendra Shah became absolute king after the royal massacre of 2001, the ground for change was visible since people felt more demoralized by inequity, poverty, inflation and civil conflict. Due to these circumstances of national trauma, the voice is dramatically raised against the unitary system. At that time, the segments of development and issue of federalism were focused along with.

Before the People's Movement, claim of federalism had got on shadow. People's Movement second has dissolved the monarchy. Maoist analyzed that development and ownership had been obstructed due to monarchial regime of long era. People' Movement 'Second' was succeeded to break up absolute monarchy and establish new democracy 
in Nepal. Due to the strength of Madhesh Movement, the amendment of Interim Constitution was made obligatory as to assure federal structure. Since Maoist had only proposed a kind of local distinctive autonomous government during its movement as its political agenda. Of course, the demand of federalism has evolved due to Maoist Movement and Madhesh Andolan even though Terai congress and other ethnic organizations had raised voice for the federal structure after the People's Movement of 1990. The issue of federal structure in Nepal has not got a long history and collective great effort to institutionalize in Nepal. On the other hand, it is believed that the demand of federal system is not an outcome of national spirit and people's voice which might be unsafe to nationality, regionalism, social order and national unity. It is also supposed that federal system is not only an alternative way for prosperity and identity. Hence several questions are being raised on this crucial issue of federalism in Nepal.

Federalism acknowledges different interests and identity as to organize under larger umbrella for ownership and prosperity. 'Federalism has to do with the need of people and politics to unite for common proposes yet remain separate to preserve their respective integrities. It is rather like wanting to have one's cake and eat too. Since that it is natural human condition, at least half the work of politics if not ninety percent of, it is directed to some how accommodating that logically for doing just that. Consequently federal ideas and arrangements have emerged repeatedly in course of human history as major devices to try to accommodate that condition. Ours is one of those time' (Walker 1981).

Principally, federalism has become a procedure to establish freedom, ownership and security to all different caste, religion, and gender. Unions have been established on basis of own features, process and different situation. Historical background, selection of governing system and recent political situations are fundamental base of union formation. Federalism is a political concept where members of a union are bound together by agreement to choose their representative head. Federalism is a democratic system. The term federalism is used to describe in system of the government where sovereignty is constitutionally divided between central authority and constituent units. There would be sharing power between federal and regional units. Nepal has become a 'federal democratic republic' nation after the third amendment of Interim Constitution 2006; even though Interim Constitution had not initially incorporated federal structure of Nepal. Nepal is now going to be restructured in federal 


\section{ISSUE OF FEDERAL SYSTEM IN NEPAL}

structure by centrifugal process. The idea of federal structure state in Nepal is originated to avoid discrimination rooted from unification era. Although the Maoist war of federalism came back strong in Nepal, it was the demand of Nepal's Janajati Party after the recovery of some Terai political parties and democracy since the beginning of Nepal's democratic movement. The Maoist insurgency demanded that the interim constitution be drafted by the Constituent Assembly, which secured a secure place in the republican constitution.

\section{CONCLUSION}

Some preparative process has been developed for institutionalizing federalism in Nepal. Some segments of development and political inclusiveness are fundamental base of demanding federal state. It has become a substantial agenda for peace, prosperity and political establishment. There are some essential characters to make matured federal structure in Nepal. National need, public interest and political possibilities are indicators of national policy. When, foundation of a state has based on highly valued diversity such as multiculturalism federal system can be adopted but such characters are not obligatory condition. National geography and peoples' desire can also play imperative role. Experience of history and its practices indicate that federalism of outcome of national interest not only interest groups and political principles. Federal states were formed as a result of national objectives, current situation and people needs. In Nepal, the issue of federal system of government is at beginning. The demand of federalism has emerged from those who are suffering by privileged. The issue of federalism is emerged by those who are suffered by all sorts of discrimination. It is hoped that federal state will end all kind of social discriminations and problems. The people who are discriminated for a long time, they want equal ownership of all segments and development. The hegemony of privileged cast has guided to federal concept in Nepal. Federalism is established in Nepal on the basis of desire of development and inclusive democracy. The issues raised by the Maoists have come to federalism in Nepal after being supported by other political parties of Nepal. After the Maoist revolution, along with its management, federalism is applied as an alternative of unitary system. 


\section{REFERENCES}

Anderson, J. (2007). Shanghiyata yek parichaya (Nepali translation). Kathmandu: UNDP.

Baral, B. (2006). Yesto Hunuparchha rajyako punasamrachana (in Nepali). Kathmandu: Bijayapur Publication.

Baral, L. (2009). Nepal federalism in a divided society. In D B Gurung N. Bharadwaj, K. Neupane, A. Acharya (eds.). Towards offederalized democratic Nepal. Kathmandu: Friends for Peace Publication. pp. 23-44.

Bhattachan, K. (2008). Minorities \& indigenous peoples of Nepal, Kathmandu: National Coalition Against Racial Discrimination.

CBS. (2012). National population and housing census 2011. (Village development committee/municipality). Kathmandu: CBS.

CBS. (2013). National population and housing census 2011. (Cast/ethnicity \& language). Kathmandu: CBS.

Congress, N. (2007), Sambidhanshabha nirbachan ghosanapatra (in Nepali). Kathmandu: Nepali Congress.

Elazar, D. (1991). Exploring federalism. Alabama: University Press of Alabama.

Hueglion, T.O. (2011). Federalism: an alternative category in political thought. In R Saxena. (ed.). Varieties of federal government major contemporary. New Delhi: Cambridge University presses India ltd. pp. 3-17.

Khanal, K. (2009). Structure and administration system of federalism republic Nepal: Alternatives and Possibilities. In DB Gurung N. Bharadwaj, K. Neupane, A. Acharya (eds.). Towards offederalized democratic Nepal. Kathmandu: Friends for Peace Publication. pp. 115-142.

Maoist, CPN. (2007). Sambidhanshabha nirbachan pratibaddatapatra (in Nepali). Kathmandu: CPN Maoist.

Nemakipa. (2010). Nepal majdur kisan party ko pratibedan (in Nepali). Kathmandu: Nepal Majdur Kisan Party.

Nepal Sarkar. (2006). Nepalko antarim Sambidhan 2063BS (in Nepali). Kathmandu: Nepal sarkar kanoon kitab byabastha samiti.

Nepal Sarkar. (2015). Nepalko Sambidhan (in Nepali). Kathmandu: Nepal Sarkar Kanoon Kitab Byabastha Samiti. 


\section{ISSUE OF FEDERAL SYSTEM IN NEPAL}

Ray, S.N. (1999). Modern comparative politics approaches methods and issues. New Delhi: Prentice hall of India Pvt. Ltd.

Regmi, D.R. (2007). Modern Nepal rise and growth in the eighteenth century, I \& II. New Delhi: Rupa \& Co.

Saxena, R. (ed), (2011). Varieties of federal government major contemporary. New Delhi: Cambridge University presses India ltd.

Topperwien, N. (2009). An introduction to federalism: The major questions. In B R Uprete, N. Topperwien, M. Heiniger. (eds.). Peace process and federalism in Nepal. Kathmandu: South Asia Regional Coordination Office, Swiss National Centre of Competence in Research (NCCR) North- South. pp. 79-94)

Upreti, S. (2009). Federalism, social justice and democracy. In DB Gurung N. Bharadwaj, K. Neupane, A. Acharya (eds.). Towards of federalized Democratic Nepal. Kathmandu: Friends for Peace Publication. pp. 143-162.

Walker, D. (1981). Toward of functioning federalism. Cambridge: Winthrop publication.

Watts, R. L. (2008). Comparing federal systems. (third eds.). London: McGill-Queen's University Press.

Wheare, K.C. (1963). Federal government. (fourth ed.). London: Oxford University Press. 